\title{
Veracruz Economic Dynamics in the Long Run: Continuities, Changes and Ruptures
}

\author{
Isabel Ortega-Ridaura \\ Research Professor in the Economic-Administrative Research Center at \\ Universidad Cristóbal Colón-UCC Boca del Río Veracruz, México \\ Email: ioridaura@gmail.com \\ Elena Moreno-García \\ Research Professor in the Economic-Administrative Research Center at \\ Universidad Cristóbal Colón-UCC Boca del Río Veracruz, México \\ Email:elenam@ucc.mx
}

Doi:10.5901/mjss.2015.v6n3p571

\begin{abstract}
The aim of this paper is to provide a quick glance of Veracruz's economic dynamics between the last decades of the 19th century and the early years of the 21th. It is based on a great variety of secondary sources (books, articles, government briefs and official documents) as well as economic censuses and state's statistics. The main processes of development and specificities that each economic model adopted are described and continuities, changes and disruptions about Veracruz economy along more than a century are identified. The analysis allows us to confirm that Veracruz has lost relevance in the national economic scene. From being the first state economy in the country, it lost its preeminence during the period of the import substitution industrialization, been replaced by states of large industrial development such as Nuevo Leon, Mexico State and Mexico City. Since then it has continued to decline up to 2009 ranking sixth place nationally after the states above mentioned as well as Jalisco and Campeche.
\end{abstract}

Keywords: Veracruz state, economics dynamics, $20^{\text {th }}$ century.

\section{Introduction}

The economic development of a country or region is molded according to past experiences and upon these, new ones are built. Therefore, to understand the current situation of Veracruz, it is important to know how different economic sectors have behaved over time.

\subsection{Objectives and methodology}

The aim of this article is to provide an overview of the main features that the economic development of Veracruz has adopted from the Porfiriato to the first decade of the $21^{\text {st }}$ century. For this purpose we've divided the paper in three sections corresponding to each of the economic models: the primary export model, the import substitution industrialization and the neoliberalism. At last, continuities, changes and disruptions about Veracruz economy along more than a century are identified.

The materials about Veracruz twentieth century, especially those related to its economic development, are scattered and fragmented in several studies on specific activity sectors (oil, sugar industry, tourism) or to determinant, historical periods as the Mexican Revolution, workers' or agricultural struggles, etc.

Under this scenario, the methodology of this paper is based on documentary research mainly from secondary sources such as books and articles, as well as primary sources including government briefs and official documents, economic censuses and state's statistics. From these, a long-term vision has been built which we present in three periods corresponding to the economic models by which México has gone: the primary export model, the model of import substitution industrialization (ISI) and the neoliberal model. In the end, it is a reflection on the continuities, changes and ruptures observed throughout its history. 


\section{Background}

\subsection{The primary export model (1880-1930)}

The inclusion of Mexico in the international division of labor took place in the last quarter of the nineteenth century, and it coincided with the long period (33 years) when Porfirio Díaz ruled the country. Mexico was incorporated into the international economy as a raw material supplier, acquiring at the same time, many of the manufactured goods in foreign markets, consumed by a small elite with high purchasing power. This development model, known as primary export, prevailed until the 1930's when the effects of the 1929 crash showed the vulnerability of the national economy and its dependence on the outside (see Cárdenas, 1995 and Villarreal, 1997).

During the Porfiriato the foundation for the industrialization of the country were established, with large investments in railways, electricity and other utilities which created a basic infrastructure for economic growth. Particularly important was the construction of the first Mexican railroad between Mexico City and the port of Veracruz launched in 1873, which stimulated commerce and industry. The possibility of bringing raw materials and move the production (textiles, sugar and products elaborated from tobacco) into the Republic enabled Veracruz to be one of the leading industrial states of the country.

Between 1875 and 1930, an industrial plant based on the production of non-durable consumer goods was formed: textiles and processing of agricultural products such as sugar cane, coffee and tobacco products. However, they constituted enclave economies with very few (or none) production chains.

The textile industry excels, whose background goes back to 1836 when the Cocolapan was installed in Orizaba, the first cotton mill and cotton fabrics (whose original owner was Lucas Alamán). Between that year and 1852 three more factories of the same type were installed in Xalapa and during the second half of the nineteenth century it had a boom characterized by its advanced technology that placed it as the spearhead of national industrialization.

The largest textile factory in Veracruz and the country for a long time was founded in 1892 in the region of Orizaba: the Río Blanco. The owners of large companies were foreigners, mostly French (known as barcelonetes). Originally they had accumulated capital by trading in Mexico, and in the late nineteenth century they came to invest in the industry, creating gigantic and ultra-modern, for that time, cotton textile mills.

On the other hand, agriculture was undoubtedly the largest source of state wealth, because of both its products linked to an exporting agro-industries sector (sugar cane and coffee) as well as the production for local consumption market (basic grains and livestock). One of the first industries established was the processing of the sugarcane, crop that in Veracruz goes back to colonial times, when the first mills (note 1) were mounted (see Chávez and Florescano, 1965). The basic period of growth of Veracruz sugar industry occurred between 1900 and 1911 . Production was multiplied six fold due to demand in the world market as a result of the destruction of the mills of Morelos during the Revolution. From 1913 Veracruz was positioned as the main national sugar producer and by 1922 contributed with 42.5 percent of the country's sugar (Bartra et. al., 1993).

Meanwhile, coffee cultivation was being expanded in the central area of the entity from the second half of the nineteenth century. Also destined for export and its main investors were foreign: german, english and american.

Cattle raising (also practiced since the colonial period) had two moments of expansion: one in the first decade of the twentieth century and another in the 1920s, spurred by the lack of coverage of domestic demand by the end of the Revolution due to the crisis in the northern livestock, as well as external demand (Olvera, 1981, p. 14).

In the late nineteenth and early twentieth century the oil industry began to gain importance, controlled by foreign companies: british, american, german, and belgian. During those years Veracruz had a dual economy: firstly an industry linked to foreign markets (sugar, coffee and cotton textiles) and another focused on immediate consumption to meet the needs of the local population (food and jute textiles). The revolutionary struggle hardly changed the economic dynamics that had been going on since the last quarter of the nineteenth century. It was not until the late twenties when the situation began to change.

The 1929 crisis severely affected export industries and in a special way to the textile industry. The drastic reduction in foreign demand highlighted the vulnerability of the domestic industry showing the first signs of depletion of this economic model. The next decade would be the turning point that marked the shift to a new economic model based on import substitution industrialization

The first agricultural and industrial censuses of the Republic were rose in 1930 and realize the status of these sectors in 1929. Such censuses clearly show the poverty and backwardness of the industry. Most of the companies were craft workshops, family companies and small manufacturing plants, and the few large-scale enterprises were located in agricultural regions and mining and oil areas (Ramos, 1975 and Amezcua, 1981). 
The essential part of life in Veracruz took place in the countryside. By 1930, 71.47 percent of the total population lived there, and its daily existence revolved around its production. 75.5 percent of the economically active state population was engaged in the agricultural sector.

Nationally, Veracruz contributed with 9.61 percent of agricultural production, 10.70 percent of the value of cattle, 8.7 percent of forest production and 15.78 percent of the value of poultry and apiaries. At that time, 8.32 percent of Mexicans were living in the entity; therefore, extra production was much higher than local needs (Olvera, 1981). Table 1 shows the major crops of the state and the percentage of its value in Veracruz and nationally.

Table 1. Percentage of value of agricultural production in Veracruz and its contribution to national production (selected products), 1930

\begin{tabular}{|c|c|c|}
\hline Product & Percentage value of the state's agricultural output & Percentage value of the state output to national level \\
\hline Corn & 32.33 & 9.63 \\
\hline Coffee & 20.30 & 41.78 \\
\hline Sugar cane & 16.88 & 22.98 \\
\hline Banana & 8.07 & 33.38 \\
\hline Vanilla & 3.72 & 97.57 \\
\hline Bean & 3.10 & 10.73 \\
\hline
\end{tabular}

Source: Cattle and Agricultural Census 1930 (quoted by Olvera, 1981).

The exportable commodities and agro-industries were mainly four crops that accounted for 72.61 percent of the value of agricultural production of the state: corn and beans, the basics, coffee and sugarcane, the agro-industries. The last two were trade worldwide. Since 1921, the sugar industry was in crisis, which worsened in 1929 with the fall in prices, accompanied by a global overproduction. Coffee suffered similar pressures in the late twenties.

Despite its importance, a very small proportion of the territory of Veracruz was destined to agriculture. Forests occupied nearly 32 percent of the total area, the third of which remained unused (the state contributed 8.7 percent of timber production in the country).

The agricultural sector was characterized by the concentration of land ownership. Common lands (known as ejidos) represented only 10 percent of the working surface. The speculative-strategic ownership stand out, linked to oil production and handled mostly by foreigners. Next to it was equally remarkable the properties owned by cattlemen who occupied besides natural grasslands, large potential agricultural areas.

On the other hand, in 1930, Veracruz was the first federal entity because of the value of its industrial production (just behind Mexico City), with 44.5 percent of workers registered in the census in big industry, in only 0.5 percent of establishments. This proportion was much higher than the national average in general and Mexico City and Nuevo Leon in particular.

The most powerful proletariat and the bourgeoisie of the country were in Veracruz, from the point of view of the concentration of production, capital and employment. Veracruz was the only entity that had three large establishments (more than 1,000 workers each) with a total of 6,497 workers. The biggest factory of the time throughout the country was the Minatitlan refinery, where 3,400 workers toiled.

Veracruz industry was essentially a set of big companies, giants for its time, with little importance of small and medium industries (Olvera, 1981, p. 33). The proportion of medium industries of Veracruz was less than others states; in contrast, the number of family workshops was much higher. This is indicative of a high degree of polarization of manufacturing production divided into a few large establishments and a multitude of small workshops producing for the local market.

In 1929 the industrial structure of Veracruz was characterized by an enormous development of five industrial branches: cotton textiles, sugar, coffee processing, oil refining and beer. All these, modern industries were operated by foreign capital and three of them traded abroad: coffee processing, sugar mills and refineries.

Most of the oil was exported crude, unrefined, so basically all this activity had an exporter character. The other two branches were integrated into the domestic market: cotton textiles and beer. They were immediate consumption goods for the national population. Table 2 shows the state's total and relative national importance of industrial production in 1930.

The 1929 census recorded 3,802 establishments in Veracruz (7.8 percent of the national total), employing 31,199 workers (11.6 percent of the national total). 
Only 122 establishments ( 3.2 percent of the total) could be considered proper industrial (small, medium and large industry) and nevertheless they employed 20,834 workers, 72.67 percent of those registered in the census.

Table 2. Relative importance of the main industries in the industrial production of the state and country, 1930

\begin{tabular}{|l|c|c|c|c|cc|cc|c|c|}
\hline & \multicolumn{2}{|c|}{$\begin{array}{c}\text { By output } \\
\text { value }\end{array}$} & \multicolumn{2}{c|}{$\begin{array}{c}\text { By number of } \\
\text { workers }\end{array}$} & \multicolumn{2}{c|}{$\begin{array}{c}\text { By number of } \\
\text { establishments }\end{array}$} & \multicolumn{2}{c|}{$\begin{array}{c}\text { By } \\
\text { investment }\end{array}$} & \multicolumn{2}{c|}{ By salary } \\
\cline { 2 - 12 } & State & Country & State & Contry & State & Country & State & Country & State & Country \\
\hline State total & 100 & 11.23 & 100 & 11.62 & 100 & 7.78 & 100 & 10.98 & 100 & 12.57 \\
\hline Cotton mills & 23.91 & 23.61 & 21.4 & 20.83 & 0.26 & 1.92 & 26.65 & 23.38 & 39.68 & 27.34 \\
\hline Sugar, alcohol, sugar mills & 18.26 & 34.94 & 13 & 26.13 & 0.89 & 22.22 & 24.74 & 30.62 & 12.21 & 36.77 \\
\hline Oil refineries & 11.99 & 96.82 & 7.9 & 94.74 & & 66.66 & 10.69 & 64.65 & 15.56 & 97.62 \\
\hline Coffee processing & 10.56 & 56.82 & 3.6 & 39.24 & 4.9 & 52.28 & 1.91 & 28.27 & 1.83 & 48.14 \\
\hline Beer & 10.4 & 24.43 & 1.6 & 20.18 & 0.1 & 13.33 & 6.37 & 26.44 & 3.13 & 15.01 \\
\hline Power plants & 3.54 & 5.25 & 2.5 & 9.24 & 1.8 & 9.9 & 10.38 & 5.11 & 5.41 & 8.25 \\
\hline Corn mills & 3.26 & 7.51 & 1.03 & 5.54 & 7.15 & 7.33 & 0.42 & 5.46 & 0.97 & 8.15 \\
\hline Bakeries & 3.17 & 9.04 & 2.27 & 9.3 & 9.83 & 10.75 & 1.74 & 6.91 & 2.9 & 9.63 \\
\hline Cigars and cigarettes & 1.97 & 5.65 & 1.55 & 12.4 & 0.65 & 18.11 & 1.14 & 3.6 & 2.01 & 10.79 \\
\hline Jute mills & 1.56 & 39.96 & 1.9 & 34.74 & - & 25 & 2.13 & 44.34 & 1.69 & 32.6 \\
\hline Grain mills & 1.3 & 2.47 & - & 1.21 & - & 0.27 & 0.78 & 1.77 & 0.22 & 2.42 \\
\hline Mechanics workshops & 1.1 & 3.67 & 1.81 & 3.61 & 1.92 & 7.41 & 0.93 & 4.04 & 3.63 & 4.29 \\
\hline Sweetener "piloncillo" and liquour "aguardiente" & 1 & 14.2 & 31.52 & 26.3 & 30.45 & 28.22 & 1.79 & 17.97 & 1.34 & 27.96 \\
\hline Soap & 0.93 & 4.2 & 0.19 & 3.32 & 0.31 & 3.64 & 0.93 & 4.23 & 0.33 & 3.78 \\
\hline Wood shops & 0.81 & 5.26 & 1.35 & 6.71 & 7.39 & 6.05 & 0.57 & 5.18 & 1.7 & 7.46 \\
\hline
\end{tabular}

Source: I Industrial Census 1930 (quoted by Olvera 1981).

The workers of the big industry were 13,914, 44.5 percent of those registered in the census, who were concentrated in just 19 establishments, with an average of 732 workers per establishment. They were five cotton textile factories, four sugar factories, a refinery, a brewery, a power plant, a jute textile factory and five large mills.

The quintessential industrial city at the time was Orizaba and foreign bourgeoisie owned practically all the great industry of Veracruz, except for some mills and sugar factories. These were mainly French and British.

According to data from the 1930 Industrial Census (quoted by Olvera, 1981), small industry was not numerous. It employed 1,839 workers (5.9 percent of the census) and it was very dispersed in 56 manufacturing establishments with an average of 32.8 workers each. They were mainly agro-industries: 16 mills, ten sugar factories and five coffee processing, which occupied a seasonal proletariat.

The craft workshops employing two or three workers were mills, bakeries, corn mills, very tiny coffee processing and other business of food industry mainly for the local market. They were altogether 1766 establishments (46.4 percent of total), with only 4,068 workers (13.1 percent). According to the author, in this level, industrial census should have already lost a lot of coverage.

Finally, family workshops, in which no wage labor was occupied, 1,262 workers (33.29 percent of total) were recorded, but probably there would be many more. Added to this, the high degree of concentration of Veracruz industry was remarkable: in only 6.15 percent of industrial establishments (about 240) 74.35 percent of the production value was generated, 70.33 percent of total capital was invested, 47.5 percent of the workers were occupied and 72.41 percent of the wages and salaries were paid. Only 47 industrial establishments explain 95 percent of the quantitative level of all variables. There were nine spinning factories and cotton fabric factories, 19 sugar factories, a refinery, 17 coffee processing and a brewery. In these, the industry of the region was concentrated (Olvera, 1981).

It is possible to observe a specialization in five branches: coffee and sugar, textil industry, oil and nondurable goods (nixtamal mills, bakeries, cigars and cigarettes, jute textil factory, grain mills, a sweetener called "piloncillo" and a liquor known as "aguardiente"), being the latter destinated to the local market and in the vast majority produced in small industries or in handcrafting workshops.

Regarding oil, by 1930 Veracruz accounted for more than 90 percent of national production. By then part of the extracted crude was processed at three refineries, being Minatitlan (which concentrated 2,459 of 2,778 workers employed in refineries) the most important. It belonged to the Compañía Mexicana de Petróleo El Águila. The main products extracted from crude were oil, lubricants, naphtha and paraffin. However, the inputs required for refining came from 
abroad and sometimes had higher value than crude itself.

\subsection{Import substitution industrialization}

The import substitution model was the dominant economic policy in Mexico since 1940 when industrialization was erected as a way to achieve development (see Ortega, 2011).

While this process of industrialization progressed, the state of Veracruz remained within the same pattern of development based on agricultural and extractive activities and therefore its industry did not evolve at the same rate than the country (Ramos, 1975, p. 29). It was a crucial period in the national and local history characterized by high population growth, transition from a rural to a predominantly urban society, and domestic industry development.

Veracruz was a major attraction area for migrants because of the significant level of development involving oil industry activity, port operations and some factories; subsequently as a consequence of demands derived from this activity combined with other services such as tourism and commerce (INE, 2007, p. 3).

In 1940, the largest city in terms of population was Orizaba, still under the impulse that the textile industry in the region had. Its decline was evident in the next decade from which the port of Veracruz experienced an unprecedented growth that continued throughout this period.

At first, this dynamism can be explained by the harbor expansion at the juncture of the Second World War and commerce activities and related services. Later, by the establishment of industries such as Tubos de Acero de México S.A. (TAMSA) in the fifties which have been catalysts for the region.

However, this growth was not necessarily followed by a similar economic development. A loss of the relative national importance of Veracruz was observed, particularly in sectors as industrial which previously headed.

Between 1930 and 1970, the number of industrial establishments in Veracruz felt down from 8.32 percent in 1930 to 5.34 percent in 1970, compared to the total establishments in the country. This brought about the relative decline on the number of employed persons, the invested capital and total gross production.

Veracruz, which was the second state in terms of establishments, labor, investment and industrial production (immediately after Mexico City) in 1930, became the fifth or sixth, depending on the chosen indicator, in 1970 (Amezcua, 1981 p. 87).

This loss of relevance of Veracruz in the national economy is observed in the declining of its contribution to Gross Domestic Product (GDP) from 7.67 percent in 1940 to 3.91 percent in 1970, meaning a 48 percent decrease (Amezcua, 1981, pp. 86 - 87).

Since 1940, the transformation industry in Veracruz was relegated to the background, and the importance of the entity at national level derived from the role that had oil production, and this was relative because by the end of this period other states began to stand out.

As the country industrialized, the regional capital accumulation continued its same traditional dynamics centered on non-durable consumption goods, in the mining and oil sector.

Table 3. Percentage of Gross State Product (GSP) to Mexico's GDP, by activities and sectors, 1940-1970

\begin{tabular}{|l|c|c|c|c|}
\hline Activities and sectors & 1940 & 1950 & 1960 & 1970 \\
\hline Agriculture & 10.12 & 9.48 & 11.53 & 17.27 \\
\hline Cattle industry & 16.13 & 6.82 & 9.99 & 15.64 \\
\hline Forestry & 32.88 & 2.54 & 3.18 & 3.49 \\
\hline Fishing & 37.18 & 13.39 & 19.73 & 18.69 \\
\hline Primary sector & 13.44 & 8.48 & 10.97 & 16.48 \\
\hline Oil & 90.00 & 85.00 & 75.00 & 62.59 \\
\hline Oil industry & 1.01 & 0.02 & 2.60 & 5.66 \\
\hline Electricity & 16.65 & 13.33 & 16.73 & 9.04 \\
\hline Construction & 3.31 & 2.18 & 2.95 & 4.57 \\
\hline Transformation industry & 7.67 & 4.02 & 4.28 & 3.91 \\
\hline Secondary sector & 13.19 & 11.12 & 11.23 & 9.46 \\
\hline Commerce & 5.71 & 2.40 & 2.12 & 2.04 \\
\hline Transportation & 7.48 & 4.93 & 6.64 & 9.89 \\
\hline Services & 6.4 & 5.05 & 5.75 & 6.37 \\
\hline Tertiary sector & 6.11 & 3.57 & 3.89 & 4.26 \\
\hline Total & 9.92 & 6.97 & 7.66 & 7.94 \\
\hline
\end{tabular}

Source: Regional Economic Statistics of the State of Veracruz, 1940-70 (quoted by Bravo, 1972). 
As shown in Table 3, from the 1950s Veracruz started to lag. Its contribution to GDP falls relative to the prior decade from 9.92 percent in 1940 to 6.97 percent. The most significant drop is observed in the primary sector whose share decreased 47 percent (from 13.44 percent to 8.48 percent) and in the tertiary, 41.5 percent (from 6.11 percent to 3.57 percent); while the secondary sector reduced its contribution to the national assembly by 16 percent, when passing from 13.9 percent to 11.12 percent.

From the data presented in Table 4, it might be concluded that this state becomes industrialized when the percentage share of secondary activities increased in the gross national product. But when we analyze by sectors, we find that this impact is due solely to the increase in share percentage of oil, which exceeds the percentage decrease in the transformation industry. This decline stems from the lack of private sector industrial investment and definitive closing of old spinning and weaving factories.

Table 4. Internal structure of the Gross State Product (GSP) of Veracruz, 1940-1970 (percentages)

\begin{tabular}{|l|c|c|c|c|}
\hline Activities and sectors & 1940 & 1950 & 1960 & 1970 \\
\hline Agriculture & 12.91 & 19.87 & 18.59 & 18.67 \\
\hline Cattle industry & 14.69 & 6.92 & 7.81 & 9.52 \\
\hline Forestry & 2.61 & 0.24 & 0.15 & 0.10 \\
\hline Fishing & 0.38 & 0.37 & 0.48 & 0.27 \\
\hline Primary sector & 30.59 & 27.40 & 27.03 & 28.56 \\
\hline Extractive industries & 0.55 & 0.01 & 0.76 & 1.30 \\
\hline Oil & 22.74 & 33.87 & 30.9 & 26.55 \\
\hline Electricity & 1.55 & 1.73 & 2.63 & 2.20 \\
\hline Construction & 0.73 & 0.99 & 1.35 & 2.25 \\
\hline Transformation industry & 14.41 & 11.86 & 12.89 & 13.50 \\
\hline Secondary sector & 39.98 & 48.46 & 48.53 & 45.80 \\
\hline Commerce & 14.88 & 9.02 & 7.16 & 5.9 \\
\hline Transports & 2.86 & 3.43 & 4.25 & 6.26 \\
\hline Services & 11.69 & 11.69 & 13.03 & 13.48 \\
\hline Tertiary sector & 29.43 & 24.14 & 24.44 & 25.64 \\
\hline Total & 100.00 & 100.00 & 100.00 & 100.00 \\
\hline
\end{tabular}

Source: Regional Economic Statistics of the State of Veracruz, 1940-1970 (quoted by Bravo, 1972).

The main Veracruz transformation industries in 1950 were sugar mills, coffee processing and breweries, very similar to 1930. By 1960 its participation in Gross State Product (GSP) increased from 11.86 percent to 11.89 percent reaching fourth place in all sectors of Veracruz. This phenomenon is the result of industrial investments in the state, especially in non-traditional items among which the steel, including the launch of TAMSA in 1954; and new food industries.

Regarding the characteristics of the manufacturing sector, most of the establishments were as small, that it can be thought that they were established to meet local demand, in the region and in many cases, the city where they were located: corn mills, bakeries, tortilla factories, and to a lesser extent, soft drink bottlers, garment, furniture stores, tire shops and construction materials, representing more than two thirds of the total establishments in 1970 (Ramos, 1975, p. 45).

Regarding the agricultural and livestock production, it significantly exceeded the proportion of inhabitants, which indicates that Veracruz contributed with agricultural inputs to the domestic market.

Tertiary activities which hardly suffered any modification in terms of percentage contribution to gross state product regarding the previous decade, did change their sectorial structure, ranking first place in these activities the services sector, which recorded a percentage increase, going from 11.69 percent to 13.48 percent. Throughout this period, oil was gradually decreasing its share in GSP due to intensive resource exploitation outside the limits of the state, mainly in the continental shelf and Tabasco State.

\subsection{Economic dynamics between 1940 and 1970}

Before ISI, Veracruz occupied a very important place in the national economy, perhaps because of the scarce industrialization of the country, its low urban concentration and its high economic dependence from abroad. These deficiencies that the national economy had by 1940, gave Veracruz a comparative advantage towards the rest of the 
country.

Since the early twentieth century, agricultural and extractive activities were the most important in the state. The exploitation of these activities contributed to the development of a large number of small and mid-size urban areas as well as an acceptable communication system. New industries were established, mostly, small business to fulfill the local population needs or to serve the demands of the agriculture and extractive sectors.

Finally, larger firms were established to exploit some of the natural resources: food processing companies (sugar mills); smelting industries; companies using perishable raw materials (fish, seafood or fruit packing) and industries that process mineral resources, such as chemical and petrochemical industries (Ramos, 1975, p. 56).

During the ISI, the state specialized in the production of raw materials for the export sector: mainly sugar and coffee in agriculture, and sulfur in mining. This specialization also covered domestic demand where oil and cattle industry were the main lines. This features an economic imbalance of Veracruz that can be noticed in three levels:

A) A regional imbalance between Veracruz and the rest of the country;

B) An interregional imbalance between the major economic areas of the state: Tuxpan, Poza Rica, Coatzacoalcos-Minatitlan, Veracruz and Córdoba-Orizaba, and the rest of the entity.

C) A critical economic dualism between the most dynamic sectors -oil and agriculture-, and the rest of Veracruz economy (Bravo, 1972, pp. 44-45).

\subsection{5: A temporary boom}

As the seventies went by, mining and transformation industry in Veracruz began to rise, followed and perhaps driven by the growth in oil production, electricity and construction (note 2).

This industrial (note 3) "boom" in the state of Veracruz is explained by the national and international situation of the seventies: The shortage of oil pushed up its prices, determining an increase in oil revenues which made affordable and profitable the opening and exploitation of new wells and technological modernization (Amezcua, 1981, p. 89). Meanwhile, the economic policy of the federal government devoted more attention and priority to regions of the country with proven oil reserves.

Parallel to the crisis overcome supported by oil, the Mexican government and the national bourgeoisie sought to reorient the country's industrial plant to the production of capital goods. The intention was to create a heavy industry of its own, that would give more dynamism to the capital accumulation in Mexico. The establishment of such industry was particularly promoted at places nearby the commodities: energy, sulfur, iron, or close to ports and exit points, characteristics both of Veracruz.

Already since 1970 the national public investment earmarked up to 75 percent of its budget to boost the oil and petrochemical industry settled in the state. Regarding a heavy, industrial plant, complementary or independent from oil, in 1970 the regional development had a slight increase along with the establishment and expansion of 39 companies with an initial capital of 2,000 million pesos in industries such as "Fertilizantes Fosfatados", "Metalúrgica Veracruzana", "Aceros Fortín", "Fibras Acrílicas", and so on, which produced for heavy industry (Amezcua, 1981, p. 90).

This process of emergence of heavy industry was accompanied by a modernization of the old Veracruz industry based on the production of non-durable consumption goods as textiles or food processing. These industries extended their facilities in response to the rise of regional demand due to the increasing urban population.

By 1975 the most dynamic branches of production in Veracruz were iron ore mining, non-metallic minerals and other non-metallic mineral products which mainly provided the raw material: sulfur, iron, silica, etc. for local and national heavy industry. These branches coexisted with those relatively new and that reflected most the industrial shift of the state: a) chemical products derived from petroleum and coal (secondary petrochemicals), including fertilizers, oils, industrial gases, etc.; b) basic metal industries, including casting of metal products, metal containers, metal structures, galvanizing, etc.; c) machinery and equipment, comprising production and reparation of metal furniture, manufacture of mechanical equipment, and tractors; d) chemical products; e) beer production; and f) manufacture and repair of machinery and tools (Amezcua, 1981, p. 97).

Unlike what happened in other states, Veracruz had many more medium and small establishments and few major industries. Data from the Industrial Census in 1975 show that of 6,016 existing industries in that year, 61.5 percent were family units. The medium industry hardly represented 1.68 percent of the total, with 103 units and the big industry 1.21 percent, hardly 74 units. Family units, craft workshops, small and medium industries, together contributed 98.62 percent of the industrial establishments, but only 12.8 percent of total gross production. While large industry with 1.25 percent of establishments generated 87.12 percent of both, production and added value. 


\subsection{Switching to neoliberalism}

The same way than in 1929, the crisis of 1982 led the country to rethink its economic model, now under neoliberal precepts. Among other measures, economy would gradually be opened, liberalizing financial markets and minimizing state intervention in the economic sphere.

Throughout the ISI, an important state-owned industry was created, especially in priority sectors for economy such as oil, electricity and steel. In 1984 the state of Veracruz had 57 state-owned companies, which were mainly located in the cities of Veracruz (26 percent), Coatzacoalcos (23 percent) and the rest along the state (Pimentel, 1986, p. 286).

The main produced goods were: chlorine and caustic soda, lime, cement and shipbuilding (shrimpers, tugboats, tuna boats, patrols and barges), steel products, sugar, alcohol and crystallized honeys. As for the services provided we find air transportation of passengers and cargo, the spread of cultural programs on television, maritime transportation and storage and shipment of products derived from sugar cane, among the most important (Pimentel, 1986, p. 286).

In the decades of 1980s and 1990s, the withdrawal of the federal investment in key sectors of the economy in Veracruz caused the closure of many companies, affecting regional economies and causing massive unemployment. The restructuring of Petróleos Mexicanos (Pemex) and the resizing of the oil economy, as well as the closing of Fertilizantes Mexicanos (Fertimex), led to a severe reduction in employment (note 4).

After 1980, Veracruz lost its relative importance as a producer of oil and gas. In turn, its contribution to national GDP continued decreasing. According to Rodríguez (1996, 2003), Veracruz contributed 20 percent of total jobs that the domestic manufacturing industry lost between 1985 and 1988.

The change of economic strategy meant a tremendous shock to Veracruz economy. In agriculture, opening of markets, liberalization of prices and transformation of systems of land ownership, have precipitated a massive and renovated population exodus from rural areas to urban centers. As a result, the primary sector on the one hand has become a major supplier of labor to other sectors of the economy but on the other, is failing as a provider of food for a growing urban population as well as of raw materials for processing industries (Acosta, 2005, p. 273). Figure 1 shows the marked decline in state production with respect to national, especially since the 1990s.

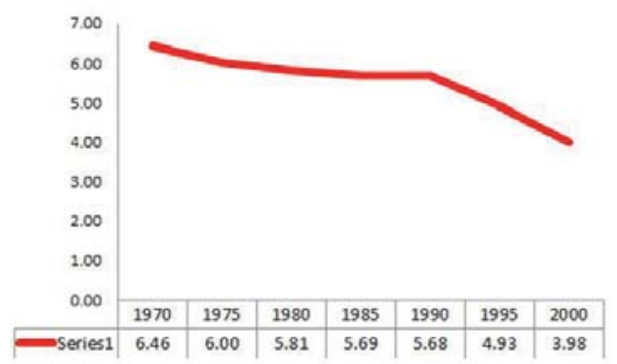

Figure 1. Percentage of Veracruz GSP compared to national, 1970-2000

Source: INEGI, Sistema de Cuentas Nacionales (data quoted in García, 2011)

Since then, manufacturing industry has consisted of nine productive branches whose participation has been very unequal. In the decade of 1990, only three of them concentrated 90 percent of the total value of manufacturing production in the state. The branch of food products, beverages and tobacco participated with 44.8 percent of total, the primary metals industry with 24.3 percent and the chemicals manufacturing industry with 20.7 percent. The other branches participate marginally: paper production, printing and publishing with 4.9 percent; the non-metallic mineral products 4.3 percent and that of textiles and apparel 0.2 percent (Secretaría de Desarrollo Económico, 2005, p. 21).

Between 1985 and 1993 the industry in Veracruz closed 16,000 positions in its most dynamic branches, and of large scale, such as petrochemical, pharmaceutical, metal structures, iron and steel, chemicals, textiles, beverages, sugar, preserves, coffee and tobacco products. Furthermore, the lack of investment flows to industrial activities, constraint the ability to provide jobs for surplus labor force released by the primary sector. As a result, the industry sector failed in its expectations of becoming the driven force of economic development.

The recession continued almost until the next crisis in 1994. The comparative advantage that the devaluation of the peso represented in 1994, helped boost exports from the region, although this occurred in three specific areas: iron and steel industry (particularly TAMSA company), chemical industry (the case of fertilizers, inorganic chemicals and plastics) and agro-industries, especially the export of coffee (Rodríguez, 2003). Despite the growth of exports in those sectors, in Veracruz around one million economically active people were unemployed in 1996. 
At the beginning of XXI century, the economic dynamics of the state was determined by 257,623 economic units, mainly distributed in commercial activities (45 percent); non-financial private services (29 percent) and manufacturing industry (15 percent).

Manufactured products in recent years have had a declining behavior. Since 1997, when the value of manufacturing output fell two percent, negative growth rates were consecutively recorded. This behavior caused that from 1996 to 2004 the value of production fell 5.5 percent, which contrasts with the national increase of 28.5 percent (Secretaría de Desarrollo Económico, 2005, p. 23).

As figure 2 shows, the most important productive sectors for the value of their production were: in first place, commerce with 18.2 percent of total state production; then the manufacturing industry with 17.9 percent; the financial services sector with 17.5 percent and community, social and personal services, with 16.8 percent.

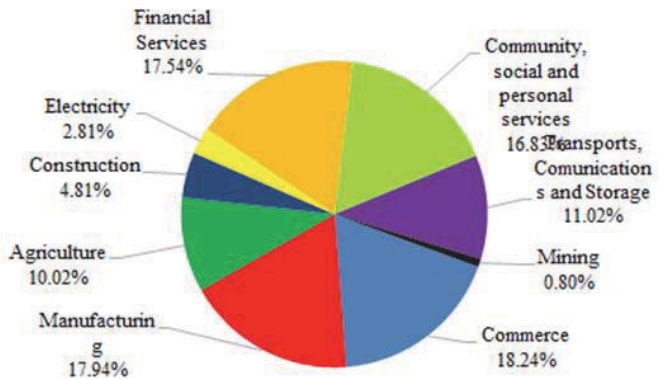

Figure 2. Veracruz. Production by sector (2002)

Source: Secretaría de Desarrollo Económico, 2005

In recent years the tertiary sector has been the most dynamic of the economy in Veracruz. However, this increasing participation is not focused on activities that can generate employment multiplier effects and increase the potential productivity of human resources, such as those related to teleinformatics and telecommunications. Instead, productivity is focused on activities related to tourism and commerce. In 2010 Veracruz was the third most populous state in Mexico and the fifth largest economy. As seen in the figure 3, that year, it contributed with 4.7 percent of GDP.

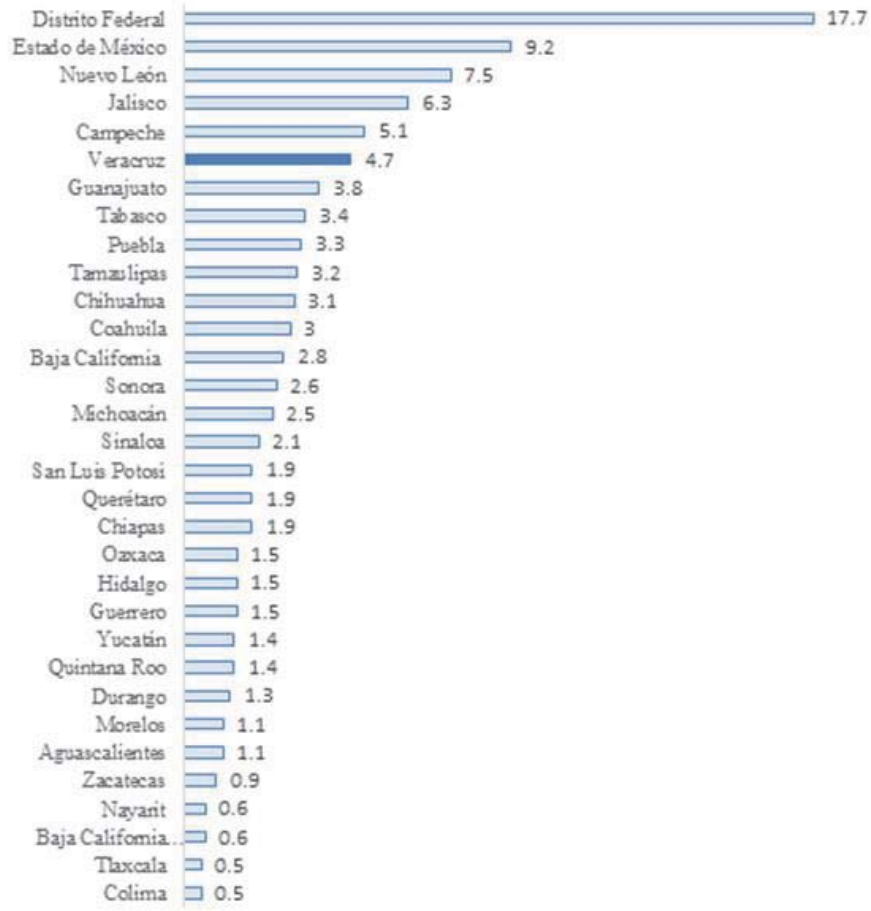

Figure 3. State Participation in Gross Domestic Product (year 2009)

Source: INEGI (2010). 
In recent years, the secondary sector of the economy (including hydrocarbons) was increasing its importance: while in 2003 it contributed 30 percent of Gross Territorial Product (GTP), by 2010 contributed almost 38 percent. In more recent years, the growth drivers of Veracruz are related to increased public investment in sectors such as energy (oil, gas and electricity), infrastructure (roads, water and sanitation, building) as well as private investment in areas such as industrial manufacturing, housing, real estate development, tourism, retail and logistic services.

The three major branches have maintained a strong growth dynamic in recent years: the metal industry with an increase of 46.1 percent and food, beverages and tobacco with 14.6 percent, while the production value of the chemicals subsector fell 34.9 percent from 1995 to 2004 (Programa Veracruzano de Desarrollo Económico y Portuario 2011 - 2016. Gobierno del Estado de Veracruz/Secretaría de Desarrollo Económico y Portuario, 2011).

The commercial sector has shown a positive trend, although it has been slowing down compared with increases of transportation and tourism. Since 1990, the hotel industry of Boca del Rio has registered important qualitative and quantitative changes, derived from the arrival of national and international hotel chains that have modified the structure of the lodge features in the city.

Under the current economic model, exportations and foreign direct investment (FDI) have taken on a new and determinant role. Export activity of the state of Veracruz grew 32.6 percent between 1999 and 2002. Export structure shows up a deep concentration on only two types of products: smelting and manufactured products of iron and steel, and organic and inorganic chemicals products. As for foreign investment, 261 companies with FDI are located in the state $(0.8$ percent of a total of 30,939 societies with foreign participation registered in the country).

The economic activity branches that have benefited from the inflow of foreign investment have been, in order of importance: the electrical industry with 39.5 percent, basic industry of iron and steel with 35.1 percent, chemicals manufacturing 23 percent, transformation and milling of cereals and other agricultural products 11.3 percent, the provision of professional, technical and specialized services 7.2 percent, manufacturing and / or assembly of transport equipment and its parts with 4.1 percent, manufacturing and / or assembly of machinery and equipment for specific tasks 2.8 percent, and wholesale of food, beverages and tobacco products 1.2 percent of the total (Secretaría de Desarrollo Económico, 2005, pp. 39-40).

Most of the companies of foreign origin in the state are located in the manufacturing sector (32 percent); 28.4 percent in commerce; 28 percent in services: community and social; hotels and restaurants; professional, technical and personal, services to the agriculture, cattle industry, construction, transport, financial and commerce. This means that only three types of economic activities concentrate 88.5 percent of all foreign companies in the state. This same pattern of concentration of investment is observed in geographical terms, since 62.5 percent of all businesses are in the metropolitan area of Veracruz-Boca del Rio.

\section{Conclusion}

The brief description we have done of the economic evolution of the entity since the late nineteenth century - during the Porfiriato - up to the beginning twenty-first century, allows us to confirm that Veracruz has lost relevance in the national economic scene. From being the first state economy in the country, it lost its preeminence during the period of the ISI, been replaced by states of large industrial development such as Nuevo Leon, Mexico State and Mexico City. Since then it has continued to decline up to 2009 ranking sixth place nationally after the states above mentioned as well as Jalisco and Campeche (See Figure 3).

Despite its decline, Veracruz has maintained a position among the top six states that contribute most to GDP. Today, it's most important sectors have diversified and include industry, energy, commerce, tourism and agro-industries. Thus, it is possible to find some continuities, changes and ruptures in remarkable sectors and economic activities, as shown below.

As for continuities, certainly the most outstanding and that can be traced to the colonial period, is the importance of the primary sector, particularly cattle industry and the cultivation of sugarcane. These activities represented in 2009 only 5.69 percent of gross state product, despite of it several products top domestic production.

Stockbreeding (especially bovine) brought to the continent by the Spaniards, is an activity that stands to date as the main national producer contributing 14.6 percent of the total raw meat (INEGI n/d).

It's also distinguishable another traditional activity that arrived with the conquerors from Spain: the cultivation of sugarcane. Veracruz produces a third of the national total (33 percent). In the early twentieth century, coffee production was added to these primary activities. The state stands second in the country, with a contribution of 22 percent nationally.

In addition to the mentioned above, another of the continuities can be found in the tertiary sector that in 2009 accounted for 58.49 percent of GSP in Veracruz. At the beginning, the centrality of this sector was in commerce, having 
the port and the activities associated to it, a prominent place. However, the composition of the tertiary sector has undergone a series of qualitative changes among which the increase of services excels.

Commerce stopped being the most relevant sector in tertiary activities to give way to an increasingly growing importance of services, particularly: 1) Transportation and logistics (mostly associated to port activity); 2) financial and real estate services; and 3) tourism services.

Another remarkable change was the emergence of tourism in the 1960s, which began to stand out as a relevant economic activity, especially since the mid- nineties with the economic liberalization that allowed the arrival of the large hotel chains.

From the 1920s, another change in state economic composition emerged with the growing importance of the oil industry, being Veracruz for several decades the main oil producer in the country. Today ranks third nationally contributing just 3.6 percent, well below Campeche and Chiapas.

The presence of refineries in Veracruz area led to the false impression that the transformation industry was relevant in the state. However, removing this item, manufacturing was quite poor. This situation has changed over time, particularly since the second half of the twentieth century with the arrival of TAMSA to Veracruz. Although of late development compared to the national experience, manufacturing has gained importance and now represents almost 14 percent of production in Veracruz, non-negligible proportion considering that at country level, this represents 17.5 percent of GDP (INEGI, 2009).

As for ruptures, without doubt the most outstanding is the disappearance of the textile industry which after practically being the pioneer of industrialization in the country in the nineteenth century, moved to Puebla and other states in the early twentieth century.

Another remarkable fact about breakups refers to the loss of relevance of Veracruz in forestry, decreasing from 33 percent at a national level to less than 3.5 percent. This is explained, in large part by the deforestation caused by the lumber industry but also by the expansion on cattle industry as well as agriculture.

With its continuities, changes and ruptures, Veracruz economy faces a major challenge: to boost capitalist development in the region to overcome the widespread economic backwardness, in order to put the local producers in conditions to take advantage of trade opening and leave behind precarious conditions on which most of the production takes place. Particularly in the agricultural sector, where a significant percentage of farmers are engaged in domestic subsistence production.

There's still a lot to be achieved. Understanding the features of Veracruz long run economic development enables us to identify trends and opportunities to regain the prominent place it deserves on the national stage.

\section{Acknowledgements}

The authors are very grateful to the anonymous reviewer for suggestions for all their help and support.

\section{References}

Acosta Barradas, R. (2005), Los desafíos de la globalización en México (Una perspectiva regional). Universidad Veracruzana, Xalapa, Veracruz.

Amezcua, H. (1989), "Industria y clase obrera en Veracruz". Márgenes, septiembre-diciembre, no. 1: 83-121.

Anguiano Téllez, M. E (2005), "Rumbo al norte: nuevos destinos de la emigración veracruzana". Migraciones Internacionales, Colegio de la Frontera Norte, enero-junio, vol. 3, no. 1: 82-110.

Bartra, A.; Aurrecoechea, J.; Espinosa, G. y Paredes, L.P. (1993), De haciendas, cañeros y paraestatales. Cien años de historia de la agroindustria cañero-azucarera en México: 1880-1980. México: UNAM-ENEP Acatlán.

Bravo Garzón, R. (1972). "Un efecto regional del desarrollo económico de México, Veracruz, 1940-1970". Dualismo, vol I, no. 1, septiembre 1971 a febrero 1972: 9-48.

Cárdenas, E. (1995), La industrialización mexicana durante la Gran Depresión. El Colegio de México, México, D.F.

Chávez Orozco, L. y Florescano, E. (1965), Agricultura e industria textil en Veracruz. Universidad Veracruzana, Veracruz.

García Aguirre, F. J. (2011), "Economía Veracruzana en el siglo XX". En Historia General de Veracruz, Gobierno del Estado de Veracruz: $485-545$.

Instituto Nacional de Ecología (2007), "Análisis del crecimiento urbano e impacto en el ambiente biofísico del área conurbada de la ciudad de Veracruz: el caso del municipio de Boca del Río". Informe Técnico del Proyecto, INE/UNAM/Secretaría de Medio Ambiente y Recursos Naturales, Noviembre de 2007.

INEGI (2010), Sistema de Cuentas Nacionales de México: Producto Interno Bruto por entidad federativa 2005-2009: año base 2003. México: Instituto Nacional de Estadística y Geografía.

Olvera, A. (1981), "La estructura económica y social de Veracruz hacia 1930. Un análisis inicial". Anuario III. Veracruz: Centro de 
Investigaciones Históricas/ Instituto de Investigaciones Humanísticas. Universidad Veracruzana: 9-58.

Ortega Ridaura, I (2011), Política fiscal e industria en Monterrey, 1940-1960. Monterrey: Universidad Autónoma de Nuevo León.

Pimentel González, O. (coord.) (1986), Veracruz, información básica. CEPES, Comité Directivo Estatal Veracruz,.

Ramos Boyoli, L. M (1975), "La industria de transformación en el desarrollo regional: el caso de Veracruz". Dualismo, vol. 4, no. 1, enero-junio 1975: 19-57.

Rodríguez, H. (1996), Movilidad social y espacio urbano en dos ciudades del Golfo de México. Tesis de Doctorado en Ciencias Sociales, Centro de Investigaciones y Estudios Superiores en Antropología Social, Universidad de Guadalajara.

Rodríguez, H. (2003), El espacio productivo de Veracruz en la más reciente época del libre cambio. Instituto de Investigaciones Histórico Sociales. Universidad Veracruzana.

Secretaría de Desarrollo Económico (2005), Programa Sectorial de Desarrollo Económico, 2005-2010. Gobierno del Estado de Veracruz.

Secretaría de Desarrollo Económico y Portuario (2001), Programa Veracruzano de Desarrollo Económico y Portuario 2011 - 2016. Gobierno del Estado de Veracruz.

Villarreal, R. (1997), Industrialización, deuda y desequililbrio externo en México. Un enfoque neoestructuralista. México: Fondo de Cultura Económica.

\section{Notes}

Note 1. The mills elaborated especially panela which was the sweetener of popular consumption since refined sugar was an export product; also used to produce liquor. It was not until the fall in world sugar prices that it became a product for the masses (Bartra et al., 1993).

Note 2. There are disparities in the quantities provided by different authors so it is not possible to perform time series of the variables except for the 1940-1970 periods (whose quantities were calculated at the Economic and Social Studies Center, Faculty of Economics at Universidad Veracruzana). In another study, data are presented for the years 1970, 1975, 1980, based on information provided by INEGI (Statistical Yearbook of Veracruz, 1984), or the Industrial Census of 1975. This may explain the differences between one table and another.

Note 3. An example of this "boom" is the fact that 83 percent of the electricity consumption in 1975 was held in the industrial sector, 10 percent was residential use and 4 percent of the commercial sector (Pimentel, 1986, p. 314).

Note 4. Only in the oil industry 24,000 jobs were lost between 1988 and 1993 (Anguiano, 2005). 